\title{
A Study on Mechanical Properties of CNT-Reinforced Carbon/Carbon Composites
}

\author{
Yi-Luen Li, Ming-Yuan Shen, Huang-Suo Su, Chin-Lung Chiang, and Ming-Chuen Yip \\ Department of Power Mechanical Engineering, National Tsing Hua University, Hsinchu 30013, Taiwan \\ Correspondence should be addressed to Ming-Chuen Yip, mcyip@pme.nthu.edu.tw
}

Received 17 January 2012; Revised 14 March 2012; Accepted 15 March 2012

Academic Editor: Sevan P. Davtyan

Copyright () 2012 Yi-Luen Li et al. This is an open access article distributed under the Creative Commons Attribution License, which permits unrestricted use, distribution, and reproduction in any medium, provided the original work is properly cited.

Carbon/carbon composites (C/C composites) possess superior characteristics of low density, high strength, extremely low coefficient of thermal expansion, and high fatigue resistance. In carbonization process, the high-temperature pyrolysis made of carbon, hydrogen, oxygen, and other elements results in a lot of voids and cavities generated in the interior of C/C composites. Therefore, the $\mathrm{C} / \mathrm{C}$ composites are densified to fill the voids by using repeated impregnation. But densification is a time-wasting and complex process, which increases production costs in the manufacturing process. In this study, the multiwall carbon nanotubes (MWNTs) were adopted as a reinforcement material for $\mathrm{C} / \mathrm{C}$ composites to reduce the existence of voids or cavities and enhance the mechanical properties of $\mathrm{C} / \mathrm{C}$ composites. According to the experimental results, the $\mathrm{CNT}$-added $\mathrm{C} / \mathrm{C}$ composite containing $1.2 \mathrm{wt} \%$ CNT possesses the greatest flexure strength, flexure modulus, and interlaminar shearing strength. Plus, the abovementioned strength and modulus are increased by $23 \%, 19.2 \%$, and $30 \%$, respectively.

\section{Introduction}

Carbon/carbon composite (C/C composite) is an abbreviation of the carbon fiber-reinforced carbon matrix composite which is reinforced by fiber. No matter fiber or matrix, both of them in composite are composed of single elemental carbon.

In 1993, Buckley and Edie [1] have stressed that the nose tip and wing tip of space shuttles have to endure the high temperatures of $2760^{\circ} \mathrm{C}$ and $1930^{\circ} \mathrm{C}$, respectively, during traveling the atmosphere. For the above-mentioned requests, $\mathrm{C} / \mathrm{C}$ composite with high-temperature high strength and light-weight properties was considered as a major material for manufacturing space shuttles.

In 1993, Savage [2] also stressed that C/C composite possesses several advantages such as high-temperature high strength, high-temperature high Young's modulus, low density, high thermal conductivity, and high fatigue resistance, hence around $60 \%$ of $\mathrm{C} / \mathrm{C}$ composites were widely used in aircrafts, braking system, and clutch.

In 1987, Fitzer [3] has mentioned that C/C composite possesses great compatibility and is antithrombotic to human body structure, blood, and skeleton, and therefore $\mathrm{C} / \mathrm{C}$ composite was selected as one of biomaterials such as artificial joint, skeleton, and heart.

As we previously mentioned the properties of $\mathrm{C} / \mathrm{C}$ composite, the advantages of carbon/carbon composite made of carbon fiber-reinforced carbon matrix include hightemperature and high elastic coefficient, low density, low thermal-expansion coefficient and high fatigue resistance.

Because of the high aspect ratio [4], low density, high strength, and high Young's modulus the carbon nanotubes (CNTs) possess, CNTs are regarded as the most suitable reinforcement material to be interfused into composites. Two difficulties occurred while CNTs were interfused into composites. Both difficulties are described as follows: the first difficulty is low interfacial strength between CNT and polymer matrix [5]; the second difficulty we met is that CNTs are hard to be evenly dispersed among matrix or resin [6]. These two difficulties must be solved first, then the superior properties of CNTs can be displayed to act as reinforcement material. Currently, the cross-linking between CNT surface and polymer matrix has been effectively improved using an adding CNT surface modifier to enhance the adhesion of interface 


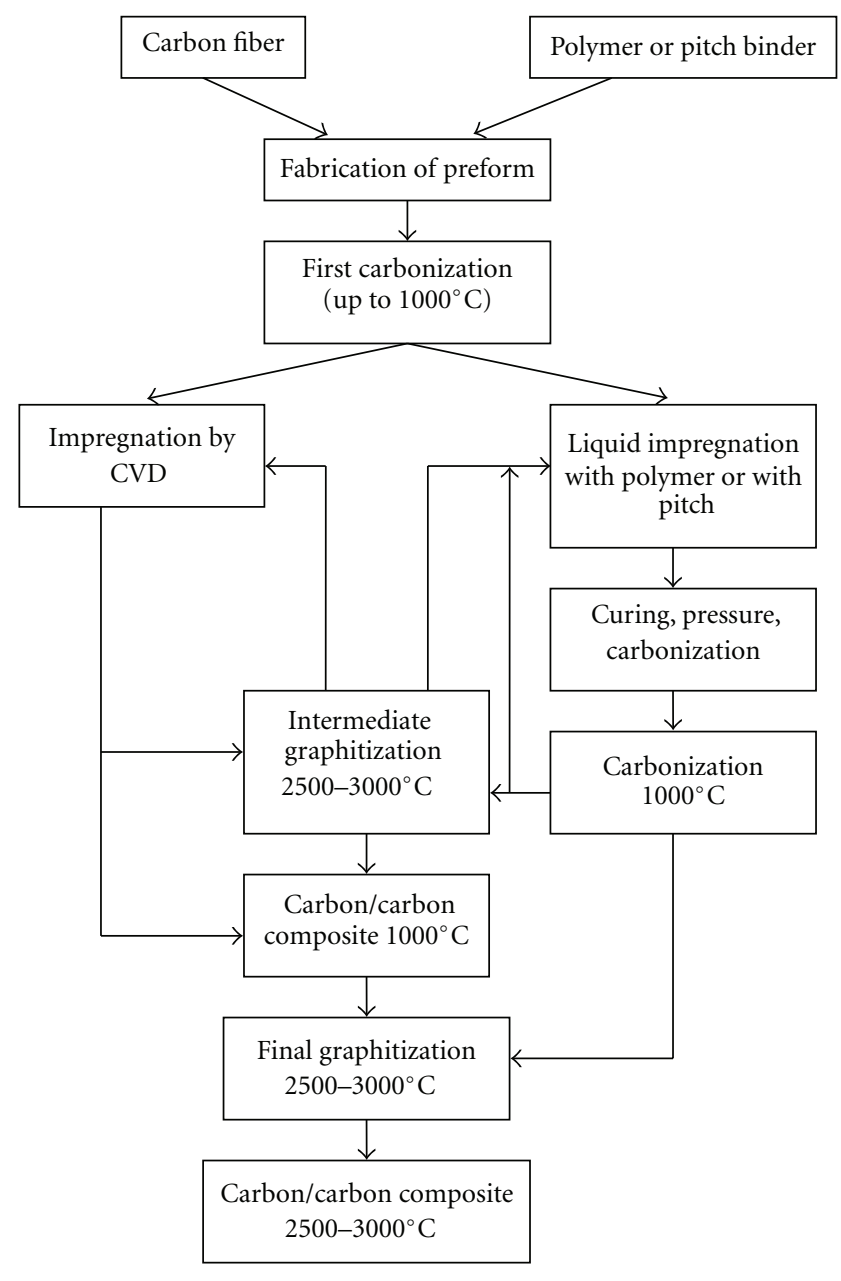

FIgURE 1: The entire manufacturing process of $\mathrm{C} / \mathrm{C}$ composite.

between CNT surface and polymer matrix. Van der Waals force makes CNTs agglomerated easily because of the high surface area of CNT, and it also influences the mechanical properties of composite. For solving agglomeration, ultrasonication and dispersant were usually adopted to improve the dispersion of CNTs among matrix in recent studies.

In this study, the various content and amount of CNTs were tried to be evenly disperse among phenolic resin $[7,8]$, and the phenolic resin solution with great CNTs dispersion was also evenly permeated through the carbon fiber cloth to prevent porous formation among the matrix during carbonization process and to make CNTs effectively deliver stress $[9,10]$.

The above-mentioned process not only can prevent porous generation among the matrix during carbonization process but also can make CNTs effectively deliver stress to properly reinforce the mechanical properties in the thickness direction of laminate.

\section{Experimental}

2.1. Manufacturing Process. In manufacturing process, carbon fiber cloth was adopted as a major material, which

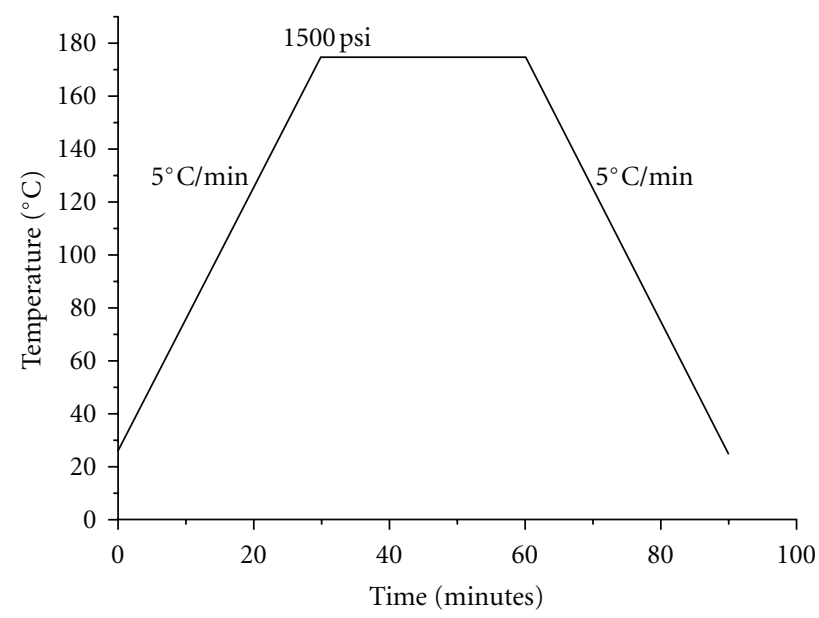

FIGURE 2: Hot pressing process of CNTs-added C/C composite.

was impregnated into phenolic resin. Heat treatment was then carried out. Next, the following treatments including carbonization, reimpregnation, and graphitization must be done to manufacture $\mathrm{C} / \mathrm{C}$ composite finally. The entire manufacturing process of $\mathrm{C} / \mathrm{C}$ composite is shown in Figure 1, and all of manufacturing treatments are described as follows.

2.1.1. Preparation of CNTs/Phenolic Resin Solution. First, the CNTs/isopropanol solution was stirred for one hour using homogenizer, then the solution was vibrated using ultrasonication for another two hours to enable CNTs to evenly disperse among the isopropanol solution. Furthermore, the CNTs/isopropanol solution was mixed with phenolic resin for one hour using mechanical mixer.

2.1.2. Carbon Fiber Cloth Impregnation. The CNTs/phenolic resin solution was placed into a vacuum heating oven and carried out the vacuum pumping for five minutes to restrain air bubble existence. The desired dimension carbon fiber cloth was placed on a release paper, and the CNTs/phenolic resin solution was evenly permeated on the carbon fiber cloth. Finally, the carbon fiber cloth with great dispersed CNTs/phenolic resin was placed into a heating oven to be exposed to a temperature at $83^{\circ} \mathrm{C}$ for 4 hours to evaporate extra solution.

2.1.3. Hot Press Molding and Postcuring. 13 pieces of prepregs were piled up into mold and placed on hot press machine to make a laminate (press at 1500 psi, temperature at $175^{\circ} \mathrm{C}$ ). Then the laminate was placed into heating oven in a temperature at $140^{\circ} \mathrm{C}$ for 3 hours to eliminate internal stress of the laminate [11]. The hot pressing process is shown in Figure 2.

2.1.4. Carbonization. The desired dimensional specimen was placed in a muffle furnace. The temperature in the muffle furnace increases at an increasing rate of $5^{\circ} \mathrm{C}$ per minute from room temperature up to $600^{\circ} \mathrm{C}$, then keep this temperature for 30 minutes and then the specimen naturally cooled 


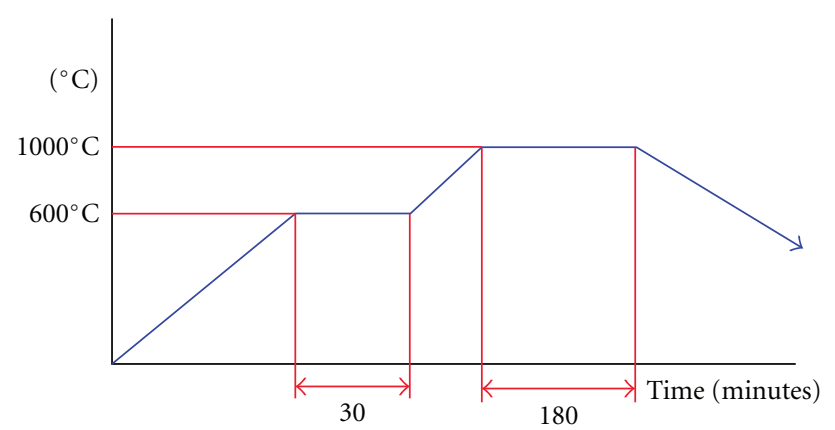

FIgURE 3: Carbonization process of CNTs-added C/C composite.

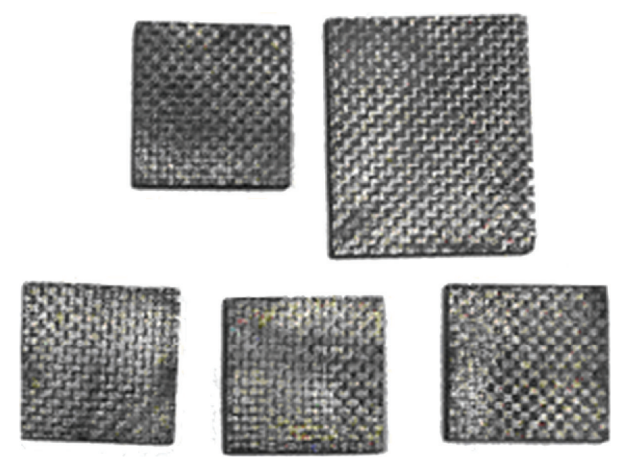

FIgure 4: Carbonized specimen.

down to room temperature. The carbonization process and carbonized specimen are shown in Figures 3 and 4, respectively.

2.2. Experimental Process. The CNTs-reinforced carbon/ carbon composites with 4 different proportions of CNT at $0.5 \mathrm{wt} \%, 1.0 \mathrm{wt} \%, 1.2 \mathrm{wt} \%$, and $1.5 \mathrm{wt} \%$ were fabricated and investigated in this study. The flexure strength test, interlaminar shearing strength test, and impact test were carried out, and the results were compared with those of CNTs-unadded carbon/carbon composites.

Furthermore, the fracture surface of specimen was investigated utilizing SEM image to figure out the dispersion status of CNTs among composites.

\section{Results and Discussion}

3.1. Flexure Strength Test Analysis. The results shown in Figure 5 and Table 1 illustrate that the flexure strength of CNTs-unadded $\mathrm{C} / \mathrm{C}$ composite is around $55.15 \mathrm{MPa}$. The flexure strength of CNTs-added reinforced C/C composite was significantly increased by $13.44 \%$ and up to $62.56 \mathrm{MPa}$ when the CNTs content increases to $0.5 \mathrm{wt} \%$. But as the CNTs content exceeds $0.5 \mathrm{wt} \%$, the enhancement of the flexure strength decreases with increasing the CNTs content. As CNTs content increases up to $1.2 \mathrm{wt} \%$, the highest flexure strength was reached and up to $67.77983 \mathrm{MPa}$, and enhancement was increased by $23 \%$, but the flexure strength starts to decrease as CNTs content increases up to $1.5 \mathrm{wt} \%$

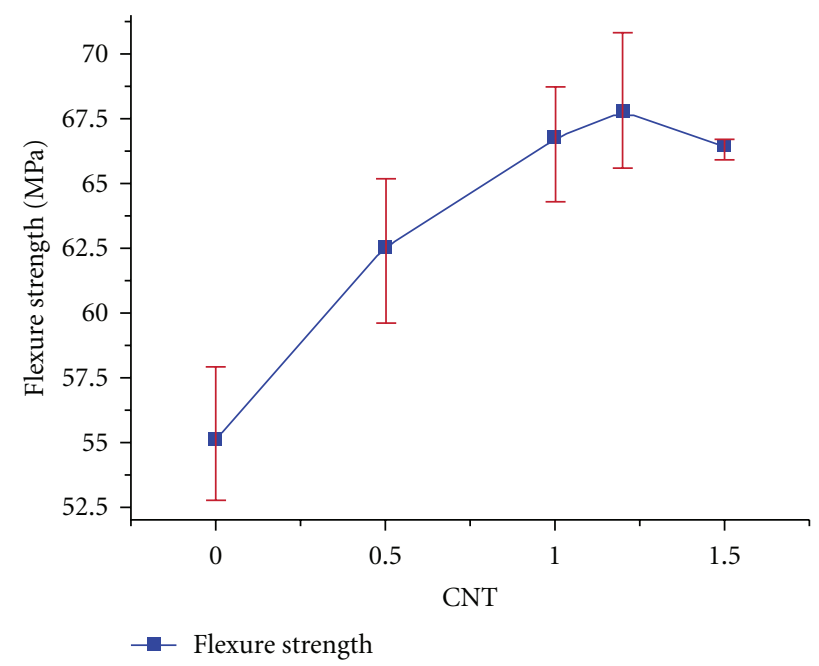

FIgURE 5: Flexure strength of CNTs C/C composite.

Table 1: Flexure strength of C/C composites and CNTs C/C composites.

\begin{tabular}{lccc}
\hline Type of C/C & $\begin{array}{c}\text { Mean } \\
\text { strength } \\
(\mathrm{MPa})\end{array}$ & $\begin{array}{c}\text { Maximum } \\
\text { strength } \\
(\mathrm{MPa})\end{array}$ & $\begin{array}{c}\text { Minimum } \\
\text { strength } \\
(\mathrm{MPa})\end{array}$ \\
\hline $\mathrm{C} / \mathrm{C}$ & 55.15 & 57.93 & 52.78 \\
$\mathrm{C} / \mathrm{C} / 0.5 \mathrm{wt} \%$ & 62.56 & 65.19 & 59.65 \\
$\mathrm{CNT}$ & 66.78 & 68.75 & 64.31 \\
$\mathrm{C} / \mathrm{C} / 1.0 \mathrm{wt} \%$ & & 70.84 & 65.62 \\
$\mathrm{CNT}$ & & & \\
$\mathrm{C} / \mathrm{C} / 1.2 \mathrm{wt} \%$ & 67.78 & 66.68 & 65.91 \\
$\mathrm{CNT}$ & & & \\
$\mathrm{C} / \mathrm{C} / 1.5 \mathrm{wt} \%$ & 66.48 & & \\
$\mathrm{CNT}$ & &
\end{tabular}

TABLE 2: Flexure modulus of C/C composites and CNTs C/C composites.

\begin{tabular}{lccc}
\hline Type of C/C & $\begin{array}{c}\text { Mean } \\
\text { modulus } \\
(\mathrm{GPa})\end{array}$ & $\begin{array}{c}\text { Maximum } \\
\text { modulus } \\
(\mathrm{GPa})\end{array}$ & $\begin{array}{c}\text { Minimum } \\
\text { modulus } \\
(\mathrm{GPa})\end{array}$ \\
\hline $\mathrm{C} / \mathrm{C}$ & 18.82 & 20.68 & 17.62 \\
$\mathrm{C} / \mathrm{C} / 0.5 \mathrm{wt} \%$ & 19.85 & 20.53 & 18.86 \\
$\mathrm{CNT}$ & 22.20 & 23.05 & 21.28 \\
$\mathrm{C} / \mathrm{C} / 1.0 \mathrm{wt} \%$ & 23.29 & 23.82 & 22.64 \\
$\mathrm{CNT}$ & & & \\
$\mathrm{C} / \mathrm{C} / 1.2 \mathrm{wt} \%$ & 22.43 & 19.37 \\
$\mathrm{CNT}$ & & & \\
$\mathrm{C} / \mathrm{C} / 1.5 \mathrm{wt} \%$ & 20.95 & & \\
$\mathrm{CNT}$ & & & \\
\hline
\end{tabular}

because agglomeration attributed to much CNTs content results in the decrease of flexure strength. Moreover, as CNTs content increases up to $1.2 \mathrm{wt} \%$, the highest flexure modulus reached up to $23.2862 \mathrm{GPa}$; the enhancement was increased by $19.2 \%$ as shown in Figure 6 and Table 2. 


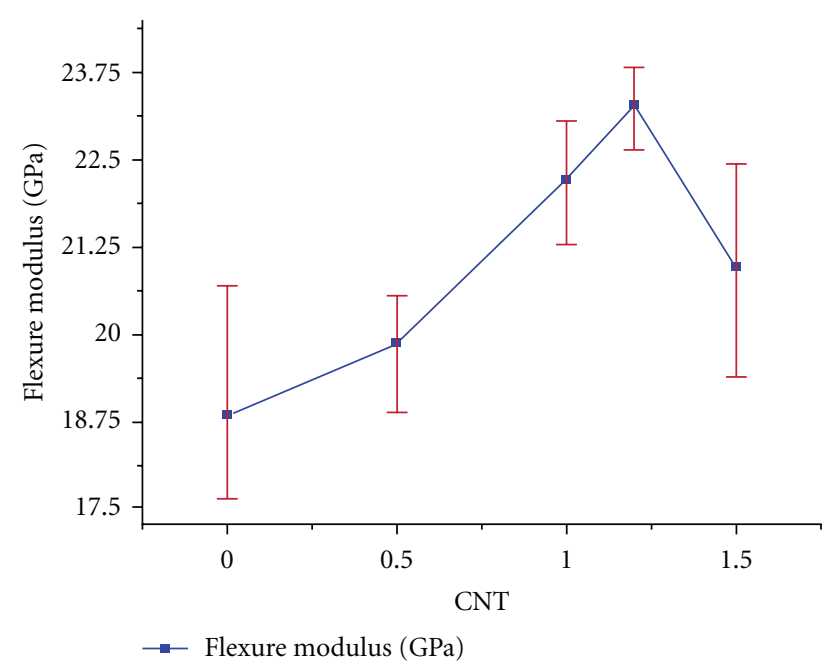

FIgURE 6: Flexure modulus of CNTs C/C composite.

3.2. Interlaminar Shearing Strength Analysis. Interlaminar shearing strength is the most important property in the thickness direction of $\mathrm{C} / \mathrm{C}$ composite laminate. In this study, short beam test was adopted to examine the interlaminar shearing strength. The results shown in Figure 7 and Table 3 display that the interlaminar shearing strength of CNTs-unadded C/C composite laminate was reached around $4.834 \mathrm{MPa}$. As CNTs content increases to $0.5 \mathrm{wt} \%$, the increase of shearing strength was not notable. But as the CNTs content exceeds $0.5 \mathrm{wt} \%$, the enhancement of the interlaminar shearing strength of CNTs-added C/C composite laminate increases with increasing the CNTs content. As CNTs content increases up to $1.2 \mathrm{wt} \%$, the highest interlaminar shearing strength was reached and up to $6.27 \mathrm{MPa}$; the enhancement was increased by $30 \%$, but the shearing strength starts to decrease as CNTs content increases up to $1.5 \mathrm{wt} \%$ because agglomeration attributed to much CNTs content results in the decrease of contacted area between CNTs and matrix and decreases the effect of resistance to delamination. Hence, the interlaminar shearing strength decreases. The failure surface of nanocomposites was examined using SEM image. The SEM image shown in Figure 8 displays that the surface of carbon fiber of CNTs-unadded C/C composite laminate looks like flatness which means the low interfacial adhesive force between CNTs and matrix, and also means that the destruction was classified as delamination failure. As CNTs content increases to $1.0 \mathrm{wt} \%$ or $1.2 \mathrm{wt} \%$, much corrugation was found in crevices among matrix shown in Figure 9. CNTs cross-link in crevices among the corrugation area to restrain the creviced growth. Corrugation and CNTs can increase the interfacial friction between carbon fiber and matrix to enhance the interlaminar shearing strength. But the shearing strength started to decrease as CNTs content increases up to $1.5 \mathrm{wt} \%$ because agglomeration attributed to much CNTs content seems to be impure to result in the stress concentration which causes crevice shown in Figure 10. Hence, the interlaminar shearing strength decreases.

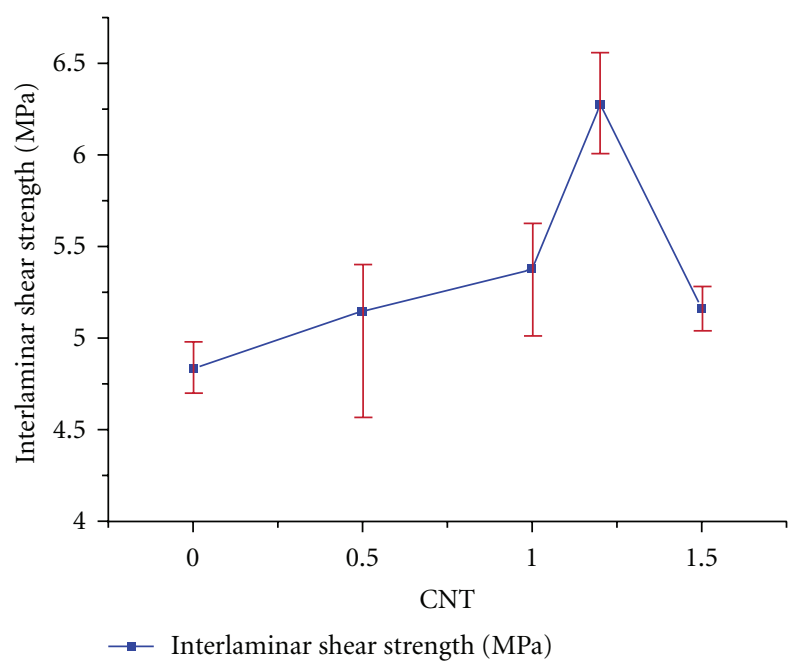

FIgURE 7: Interlaminar shearing strength of CNTs C/C composite.

TABLE 3: Interlaminar shearing strength of $\mathrm{C} / \mathrm{C}$ composites and CNTs C/C composites.

\begin{tabular}{|c|c|c|c|}
\hline Type of C/C & $\begin{array}{c}\text { Mean } \\
\text { strength } \\
(\mathrm{MPa})\end{array}$ & $\begin{array}{c}\text { Maximum } \\
\text { strength } \\
(\mathrm{MPa})\end{array}$ & $\begin{array}{c}\text { Minimum } \\
\text { strength } \\
(\mathrm{MPa})\end{array}$ \\
\hline $\mathrm{C} / \mathrm{C}$ & 4.83 & 4.98 & 4.70 \\
\hline $\begin{array}{l}\mathrm{C} / \mathrm{C} / 0.5 \mathrm{wt} \% \\
\mathrm{CNT}\end{array}$ & 5.15 & 5.40 & 4.57 \\
\hline $\begin{array}{l}\mathrm{C} / \mathrm{C} / 1.0 \mathrm{wt} \% \\
\mathrm{CNT}\end{array}$ & 5.38 & 5.63 & 5.01 \\
\hline $\begin{array}{l}\mathrm{C} / \mathrm{C} / 1.2 \mathrm{wt} \% \\
\mathrm{CNT}\end{array}$ & 6.27 & 6.55 & 6.00 \\
\hline $\begin{array}{l}\mathrm{C} / \mathrm{C} / 1.5 \mathrm{wt} \% \\
\mathrm{CNT}\end{array}$ & 5.16 & 5.28 & 5.04 \\
\hline
\end{tabular}

TABle 4: Impacting energy of $\mathrm{C} / \mathrm{C}$ composites and CNTs $\mathrm{C} / \mathrm{C}$ composites.

\begin{tabular}{lccc}
\hline Type of C/C & $\begin{array}{c}\text { Mean energy } \\
(\mathrm{J} / \mathrm{m})\end{array}$ & $\begin{array}{c}\text { Maximum } \\
\text { energy }(\mathrm{J} / \mathrm{m})\end{array}$ & $\begin{array}{c}\text { Minimum } \\
\text { energy }(\mathrm{J} / \mathrm{m})\end{array}$ \\
\hline $\mathrm{C} / \mathrm{C}$ & 25.17 & 25.68 & 24.73 \\
$\mathrm{C} / \mathrm{C} / 0.5 \mathrm{wt} \%$ & 24.74 & 27.57 & 22.38 \\
$\mathrm{CNT}$ & 24.29 & 27.83 & 22.44 \\
$\mathrm{C} / \mathrm{C} / 1.0 \mathrm{wt} \%$ & 24.76 & 25.63 & 23.55 \\
$\mathrm{CNT}$ & & & \\
$\mathrm{C} / \mathrm{C} / 1.2 \mathrm{wt} \%$ & 26.74 & 31.52 & 23.94 \\
$\mathrm{CNT}$ & & & \\
$\mathrm{C} / \mathrm{C} / 1.5 \mathrm{wt} \%$ & &
\end{tabular}

3.3. Impacting Energy Analysis. From the results shown in Figure 11 and Table 4, the impacting energy does not apparently increase whether CNTs were added into matrix or not. Because the failure mode of impact test is the fiber breakage dominated by fiber, CNTs do not notably influence on resistance to impact whether CNTs were added into matrix or not. But in the carbonization process, the 


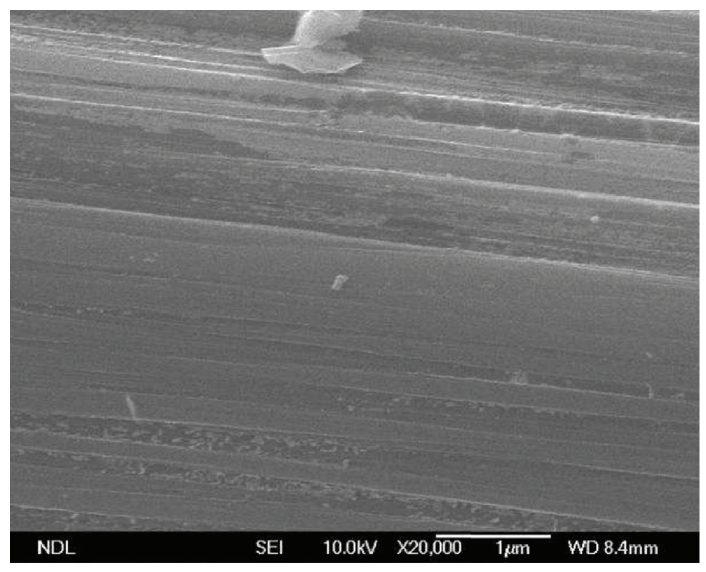

(a)

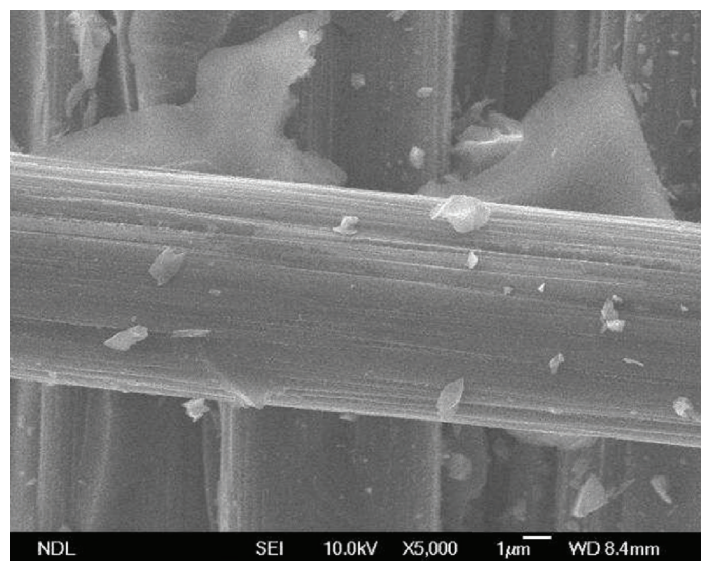

(b)

FIgURE 8: Fracture surface of interlaminar shearing strength of CNTs C/C composite. (a) $5000 \times$ and (b) $20000 \times$.

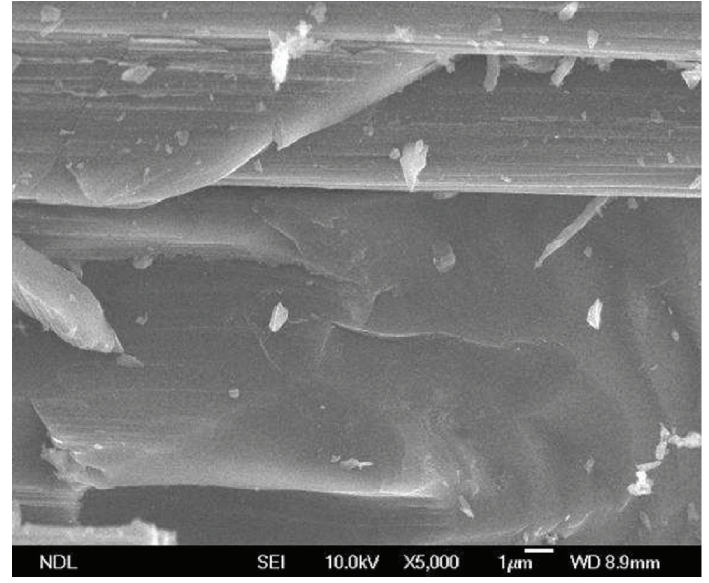

(a)

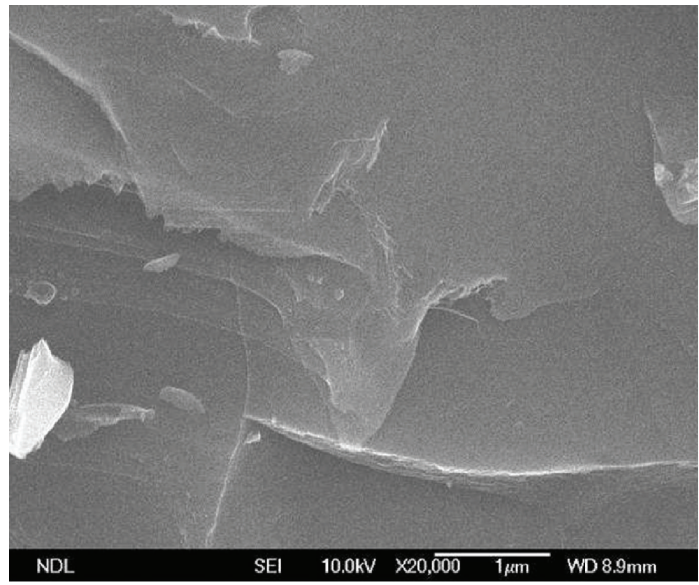

(b)

FIGURE 9: Fracture surface of interlaminar shearing strength of $1.2 \mathrm{wt} \% \mathrm{CNTs} C / \mathrm{C}$ composite. (a) $5000 \times$ and (b) $20000 \times$.

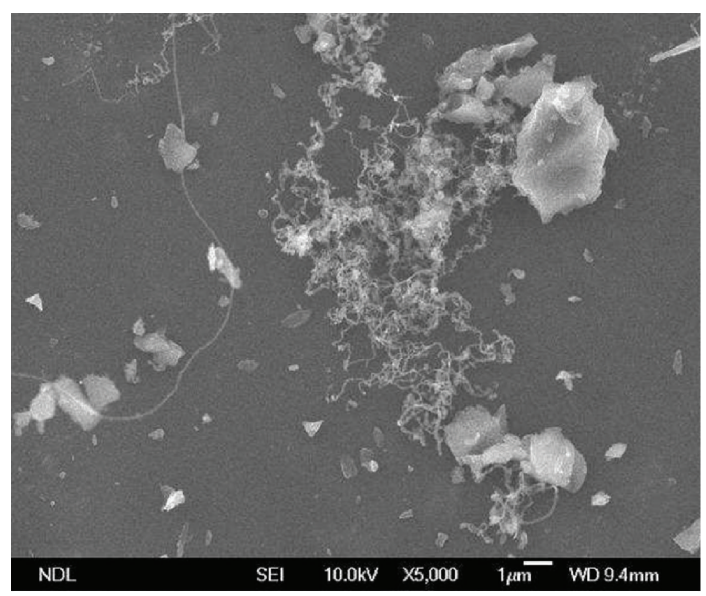

(a)

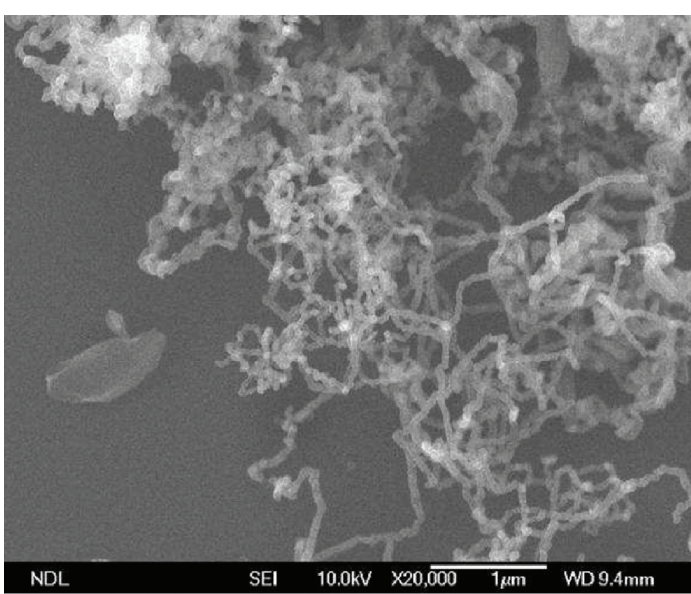

(b)

FIGURE 10: Fracture surface of interlaminar shearing strength of $1.5 \mathrm{wt} \% \mathrm{CNTs}$ C/C composite. (a) $5000 \times$ and (b) $20000 \times$. 


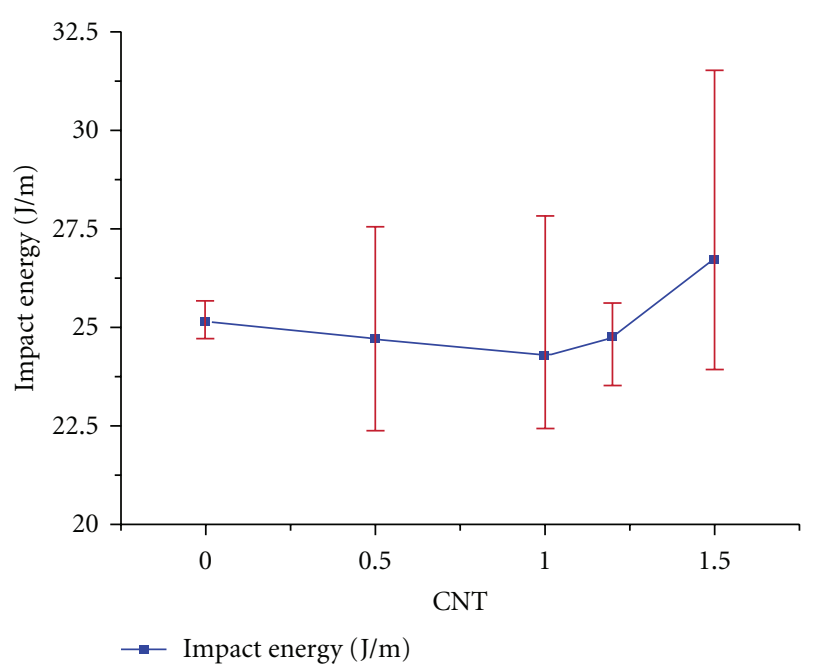

Figure 11: Impacting energy of CNTs C/C composite.

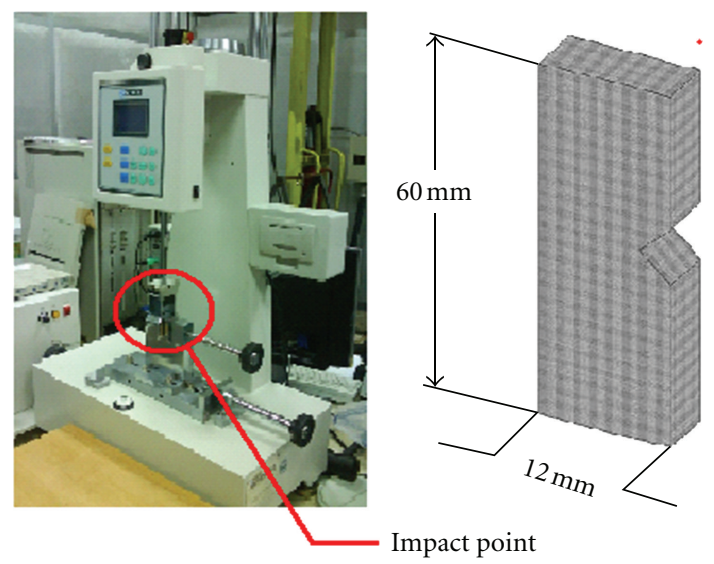

FIGURE 12: Impact testing machine and system.

fracture, break, and crevice occurred on the surface of carbon fiber exposed to the high temperature do notably influence resistance to impact. The impact testing machine and system were equipped as shown in Figure 12.

\section{Conclusion}

The flexure strength, flexure modulus, and interlaminar shearing strength of CNTs-added C/C composites are higher than those of CNTs-unadded $\mathrm{C} / \mathrm{C}$ composites. Because the cross-link of high strength CNTs among microcrevices can stop creviced growth and make crevices tortuous to effectively restrain the creviced growth, the above-mentioned function of CNTs can increase the flexure strength, flexure modulus, and interlaminar shearing strength. Furthermore, as CNTs content increases up to $1.2 \mathrm{wt} \%$, the highest flexure strength, flexure modulus, and interlaminar shearing strength were increased.

Impact test is the fiber breakage dominated by fiber. CNTs do not notably influence resistance to impact whether CNTs were added into matrix or not.

\section{Acknowledgments}

The authors are grateful for the help of the Center for Nanotechnology, Materials Science, and Microsystems at the National Tsing Hua University, Taiwan. Ted Knoy is appreciated for his editorial assistance.

\section{References}

[1] J. D. Buckley and D. D. Edie, Carbon-Carbon Materials and Composites, Noyes, 1993.

[2] G. Savage, Carbon-Carbon Composites, Chapman \& Hall, London, UK, 1993.

[3] E. Fitzer, "The future of carbon-carbon composites," Carbon, vol. 25, no. 2, pp. 163-190, 1987.

[4] F. H. Gojny, M. H. G. Wichmann, B. Fiedler, W. Bauhofer, and K. Schulte, "Influence of nano-modification on the mechanical and electrical properties of conventional fibrereinforced composites," Composites Part A, vol. 36, no. 11, pp. 1525-1535, 2005.

[5] F. H. Gojny and K. Schulte, "Functionalisation effect on the thermo-mechanical behaviour of multi-wall carbon nanotube/epoxy-composites," Composites Science and Technology, vol. 64, no. 15, pp. 2303-2308, 2004.

[6] E. Najafi, J. Y. Kim, S. H. Han, and K. Shin, "UV-ozone treatment of multi-walled carbon nanotubes for enhanced organic solvent dispersion," Colloids and Surfaces A, vol. 284285, pp. 373-378, 2006.

[7] Y. S. Song and J. R. Youn, "Influence of dispersion states of carbon nanotubes on physical properties of epoxy nanocomposites," Carbon, vol. 43, no. 7, pp. 1378-1385, 2005.

[8] M. A. Kiselev and A. I. Kuzayev, "Preparation and properties of silicone Modified Phenol-Formaldehyde Resin," U.S Patent 2685054, 1968.

[9] S. E. Hsu and C. I. Chen, "The processing and properties of some C/C system," in Superalloys, Supercomposites and Superceramics, J. K. Tien and T. Caulfield, Eds., pp. 721-744, Academic Press, San Diego, Calif, USA, 1989.

[10] J. M. F. De Paiva, S. Mayer, and M. C. Rezende, "Evaluation of mechanical properties of four different carbon/epoxy composites used in aeronautical field," Materials Research, vol. 8, no. 1, pp. 91-97, 2005.

[11] B. C. Ray, "Temperature effect during humid ageing on interfaces of glass and carbon fibers reinforced epoxy composites," Journal of Colloid and Interface Science, vol. 298, no. 1, pp. 111$117,2006$. 

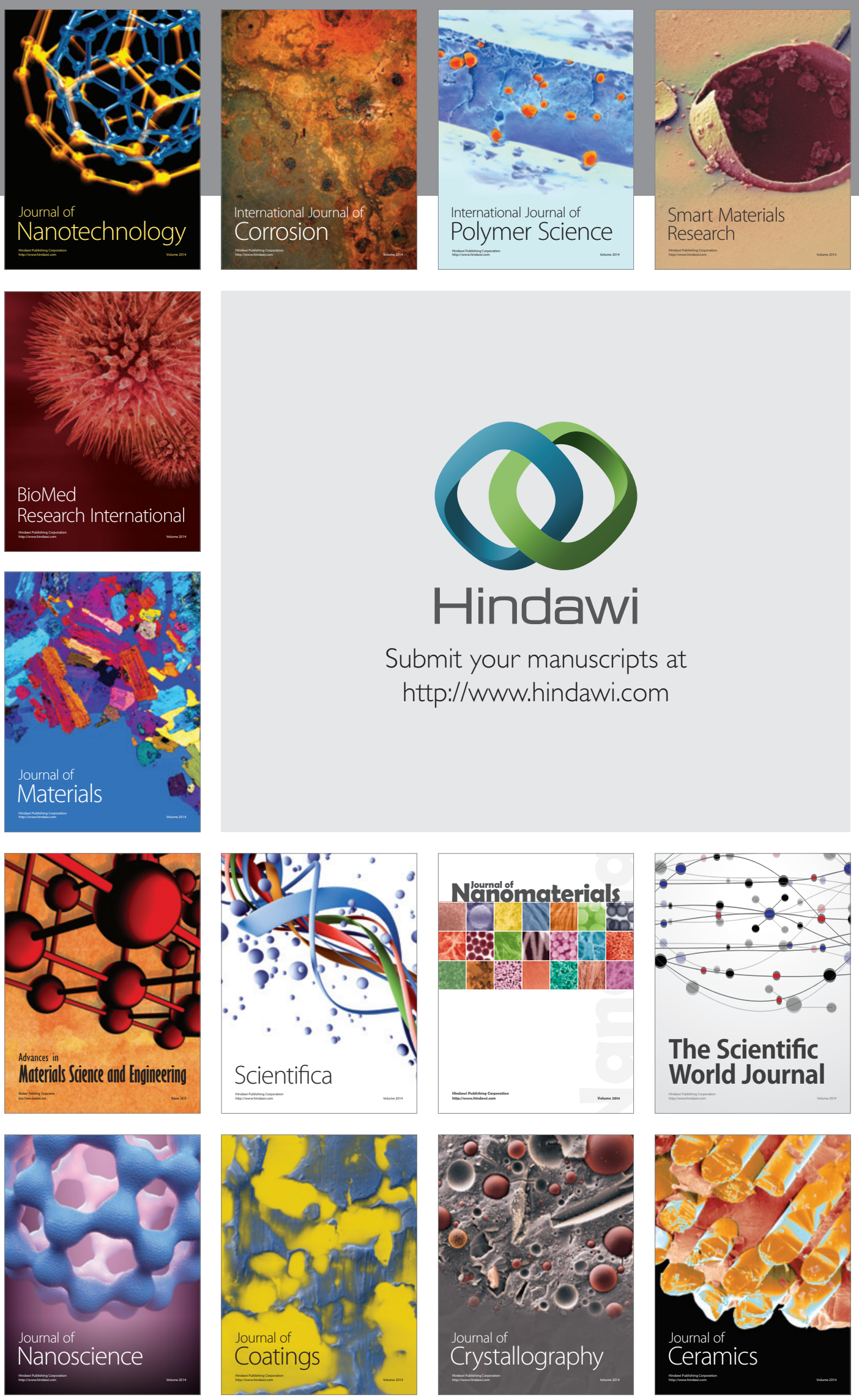

The Scientific World Journal

Submit your manuscripts at

http://www.hindawi.com

\section{World Journal}

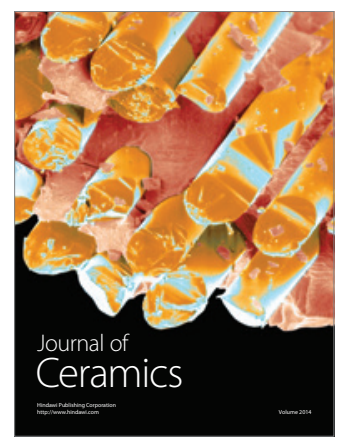

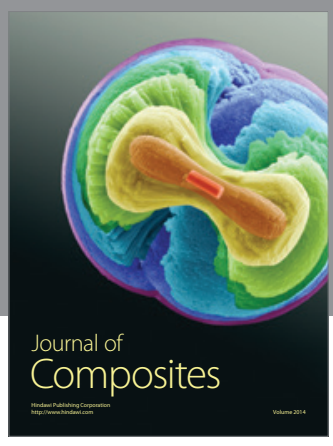
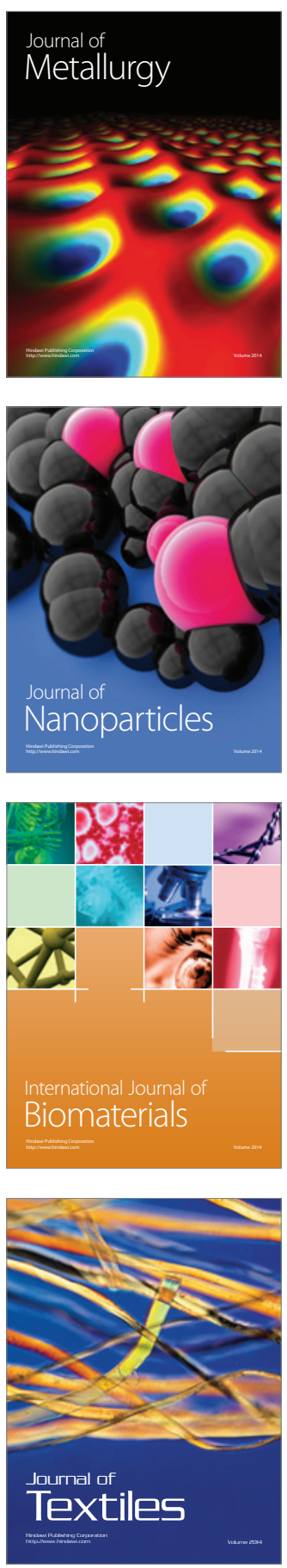